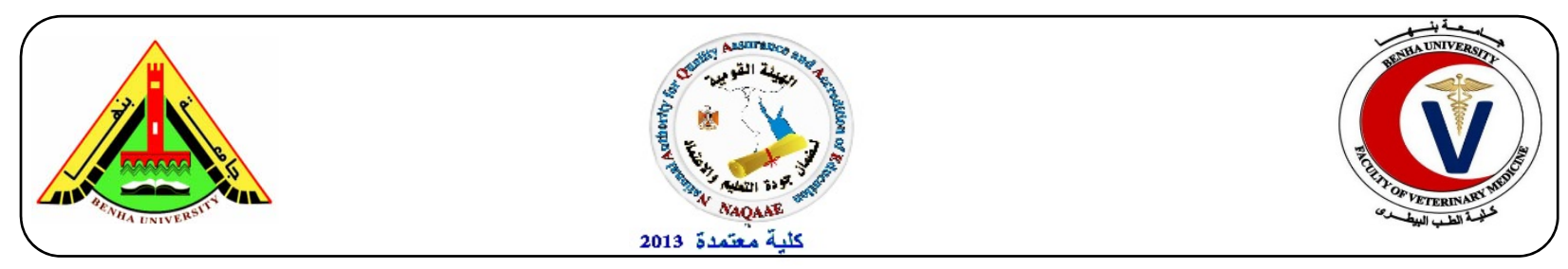

\title{
Biochemical changes in the body of obese persons undergoing weight reduction program.
}

Yakout A. El-Sanosi' ${ }^{1}$, Abdel-Shafi El-M.Tabl ${ }^{2}$, Ghada M. El-Basyouni ${ }^{3}$, Marwa M.F. Atta ${ }^{1}$

${ }^{1}$ Department of Food Control, Faculty of Veterinary Medicine, Benha University. ${ }^{2}$ Department of

Internal Medicine, Faculty of Medicine; Benha University. ${ }^{3}$ Department of Nutrition and food science, Faculty of specific education (Home Economics), Faculty of Medicine; Benha University.

\section{A B S T R A C T}

Obesity results from fat accumulation in the body \& results in multiple organ-specific pathological consequences. The prevalence of overweight and obese people is increasing worldwide at an alarming rate in both developing and developed countries. Weight reduction in obese patients is associated with an improvement of their health. This study aims to assessing the biochemical changes in the body of obese persons undergoing weight reduction program (WRP). The study was carried out on two groups, group I consists of (forty four (44) obese persons) with body mass index more than 30 undergoing WRP through diet and exercise \& group II consists of (forty (40) obese persons not undergoing WRP as controls). The diet plan is the critical factor for weight loss, eating less \& exercise more help to lose weight faster. Results of this study prove \& magnify the beneficial value of WRP for obese persons in group I \& explain its effects through the following: Significant reduction in body weight; Body Mass Index (BMI); Improvement (significant decrease) of: both systolic and diastolic blood pressure, blood glucose level, serum uric acid, serum creatinine, total serum cholesterol, LDLc \& serum triglycerides; as well as significant increase of the protective lipid (HDLc). Also, there is improvement of liver function tests, i.e. significant decrease of liver enzymes (SGOT \& SGPT) \& significant increase of serum albumin. Overweight \& obese persons should follow a program for weight reduction as early as possible \& obese persons should investigate their biochemical changes regularly.

Keywords: Overweight, Obesity, Weight Reduction Program, Biochemical Changes.

(http://www.bvmj.bu.edu.eg)

(BVMJ-29(1):63-73, 2015)

\section{INTRODUCTION}

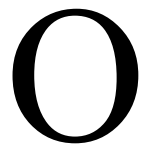
besity is the disease process characterized by excessive body fat accumulation with complex genetic-environmental etiology, which results in multiple organ-specific pathological consequences (Han et al, 2011). Obesity is, also, defined by a body-mass index (weight divided by square of the height) of $30 \mathrm{~kg} / \mathrm{m} 2$ or greater (Kopelman, 2000). The prevalence of overweight and obese people is increasing worldwide at an alarming rate in both developing and developed countries (Fitch et al, 2013). The economic burden of the obesity epidemic is enormous (Finkelstein et al, 2003). Obesity accounts for $2-6 \%$ of total health care costs in several developed countries (WHO, 2003). Weight reduction as little as 5\% in obese patients is associated with an improvement in the cardiovascular risk profile, a decrease in the incidence of diabetes, and the reduction of pain associated with osteoarthritis (Meredith 
et al, 2011). This study aims to assessing the biochemical changes in the body of obese persons undergoing weight reduction program.

\section{MATERIAL AND METHODS}

The study was carried out on two groups, group I: consists of forty four $(\mathrm{N}=44)$ obese persons with body mass index more than 30 undergoing WRP through diet and exercise \& group II: consists of forty $(\mathrm{N}=40)$ obese persons not undergoing WRP as controls. It was performed on attendants of "fit gym center" in Mansoura city, Dakahlia governorate who agree to participate in this study; during a time period of six months from March 2014 to September 2014. Controls were selected from their relatives \& followers who are cross matched in age \& sex. The only difference between both groups of this study is the involvement in the program of weight reduction. Every person included in this work was interviewed at beginning of this study with a questionnaire including socio-demographic data e.g. name, age, sex, residence, education, occupation, phone number, past $\&$ family history of some diseases (DM, Hypertension \& Gout) as well as History of trying to follow weight reduction program. Also, all subjects in this study were subjected to measuring weight (in kilograms) and height (in meters) as well as blood pressure (in $\mathrm{mmHg}$ ). Baseline Anthropometric measurements (at the beginning of the study) were used to calculate body mass index (BMI) as weight in kilograms $(\mathrm{kg})$ divided by height in squared meters $\left(\mathrm{m}^{2}\right)$ (Thang et al 2006). At the end of the study, Body weight (BW) was assessed to track weight changes. Percent weight reduction was calculated using the following equation: [(initial BW - \{final BW)/initial

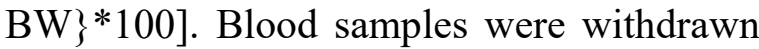
early in the morning, before breakfast and after 12 hours overnight fast. Blood sample (fresh blood) was centrifugated at $3000 \mathrm{rpm}$ for 15 minute and serum was separated within 2 hours of the collection and used for the following biochemical investigations: Fasting blood glucose normal value $70-110 \mathrm{mg} / \mathrm{dL}$ (McMillin 1990), Lipid profile i.e. Serum cholesterol $<200 \mathrm{mg} / \mathrm{dL}$ : HDLc (high density lipoprotein cholesterol) recommended range $>35 \mathrm{mg} / \mathrm{dL}$, and LDLc (low density lipoprotein cholesterol) recommended range $<130 \mathrm{mg} / \mathrm{dL}$ as well as Serum triglycerides (normal value 40-150 $\mathrm{mg} / \mathrm{dL}$ ) (Cox et al 1990), Serum uric acid Normal range: 2.0-7.0 mg/dL (Barr 1990), Serum creatinine (Normal range: 0.6-1.2 $\mathrm{mg} / \mathrm{dL}$ ) (Hosten1990), SGOT (Serum Glutamic Oxaloacetic Transaminase) normal value in female 6-34 IU/L \& male 8-40 IU/L (Vroon et al), SGPT (Serum Glutamic Pyruvate Transaminase) normal value in female 5-38 IU/L \& male 10-50 IU/L, Serum albumin Normal value is $3.5-5.0 \mathrm{~g} / \mathrm{dl}$ (Busher 1990), while blood sample on EDTA used for Blood $\mathrm{Hb}$ analysis, The normal $\mathrm{Hb}$ level for males is 14 to $18 \mathrm{~g} / \mathrm{dl}$; that for females is 12 to $16 \mathrm{~g} / \mathrm{dl}$ (Billett 1990).

\section{RESULTS}

Table (1) clarifies that obese persons of group II consists of (forty (40) obese persons not undergoing WRP as controls) are cross matched to those of group I regarding their gender (sex), age, residence, education and occupation. This means that there is no significant differences between both groups regarding these socio-demographic characteristics $(P>0.05)$. However, in both groups obesity is more common in females, Middle aged persons, rural residents, those with higher education \& employed subjects. Another presentation in table (2) reveals that both groups are nearly similar as regards their mean values of age. 
Table (1): Distribution of the studied groups according to some socio-demographic characteristics at the beginning of the study.

\begin{tabular}{|c|c|c|c|c|c|c|}
\hline \multirow[b]{2}{*}{ Characteristic } & \multicolumn{2}{|c|}{$\begin{array}{c}\text { Group I }^{1} \\
(\mathrm{n}=44)\end{array}$} & \multicolumn{2}{|c|}{$\begin{array}{c}{\text { Group } \mathrm{II}^{2}}_{(\mathrm{n}=40)}\end{array}$} & \multicolumn{2}{|c|}{$\begin{array}{l}\text { Total } \\
(\mathrm{n}=84)\end{array}$} \\
\hline & No. & $\%$ & No. & $\%$ & No. & $\%$ \\
\hline \multicolumn{7}{|l|}{ Sex:* } \\
\hline - Males : & 20 & 45.5 & 18 & 45.0 & 38 & 45.2 \\
\hline - Females : & 24 & 54.5 & 22 & 55.0 & 46 & 54.8 \\
\hline \multicolumn{7}{|l|}{ Age:* } \\
\hline$* 30$ & 9 & 20.5 & 7 & 17.5 & 16 & 19.0 \\
\hline$* 30-$ & 28 & 63.6 & 30 & 75.0 & 58 & 69.0 \\
\hline$*>45$ & 7 & 15.9 & 3 & 7.5 & 10 & 12.0 \\
\hline \multicolumn{7}{|l|}{ Residence:* } \\
\hline - Urban: & 35 & 79.5 & 33 & 82.5 & 16 & 19.0 \\
\hline - Rural: & 9 & 20.5 & 7 & 17.5 & 68 & 81.0 \\
\hline \multicolumn{7}{|l|}{ Education:* } \\
\hline$>$ Low: & 12 & 27.3 & 10 & 25.0 & 22 & 26.2 \\
\hline > High: & 32 & 72.7 & 30 & 75.0 & 62 & 73.8 \\
\hline \multicolumn{7}{|l|}{ Occupation:* } \\
\hline > Unemployed: & 21 & 47.7 & 17 & 42.5 & 38 & 45.2 \\
\hline$>$ Employed: & 23 & 52.3 & 23 & 57.5 & 46 & 54.8 \\
\hline
\end{tabular}

${ }^{1}$ This group includes obese persons undergoing weight reduction program. ${ }^{2}$ These are obese persons not follow any intervention (controls for group I). * statistically insignificant differences, ${ }^{* *}$ statistically significant differences.

Table (2): Comparison between the studied groups regarding their age at the beginning of the study.

\begin{tabular}{lcc}
\hline $\begin{array}{l}\text { Age } \\
\text { (years): }\end{array}$ & $\begin{array}{c}\text { Group I } \\
(\mathrm{n}=44)\end{array}$ & $\begin{array}{c}\text { Group II } \\
(\mathrm{n}=40)\end{array}$ \\
\hline Range: & $25-49$ & $26-50$ \\
& $36.57 \pm 6.66^{*}$ & $35.90 \pm 5.95^{*}$
\end{tabular}

*Insignificant difference

The difference between both groups is statistically insignificant $(P>0.05)$. Table (3) shows that both groups are obese persons (BMI $\geq 30)$. The differences between both groups regarding body weight \& body mass index are statistically insignificant $(P>0.05)$. It is evident from table (4) that both groups are similar regarding their hypertensive state as well as their diabetic state i.e. both groups are cross matched with a statistically insignificant differences $(P>0.05)$. About quarter of both groups (obese persons) are hypertensive. Also, Diabetics \& borderline cases constitute about one third of obese subjects. Another presentation in table (5) reveals that both groups are nearly similar as regards their mean values of systolic and diastolic blood pressure. The differences between both groups are statistically insignificant $(P>0.05)$. Table (6) shows that at the beginning of the study, both groups are cross matched regarding their weight, height\& body mass index. Table (7) clarifies the cross matching state between both groups regarding their fasting blood glucose, serum uric acid, serum creatinine, blood hemoglobin, lipid profile and liver function tests at the beginning of the study. The differences between mean values of the mentioned laboratory investigation are statistically insignificant $(P>0.05)$. Table (8) demonstrates the significant decrease in body weight and body mass index within the group I after WRP $(P>0.01)$. The mean value of 
Table (3): Distribution of the studied groups according to body weight, height and body mass index (BMI) at the beginning of the study.

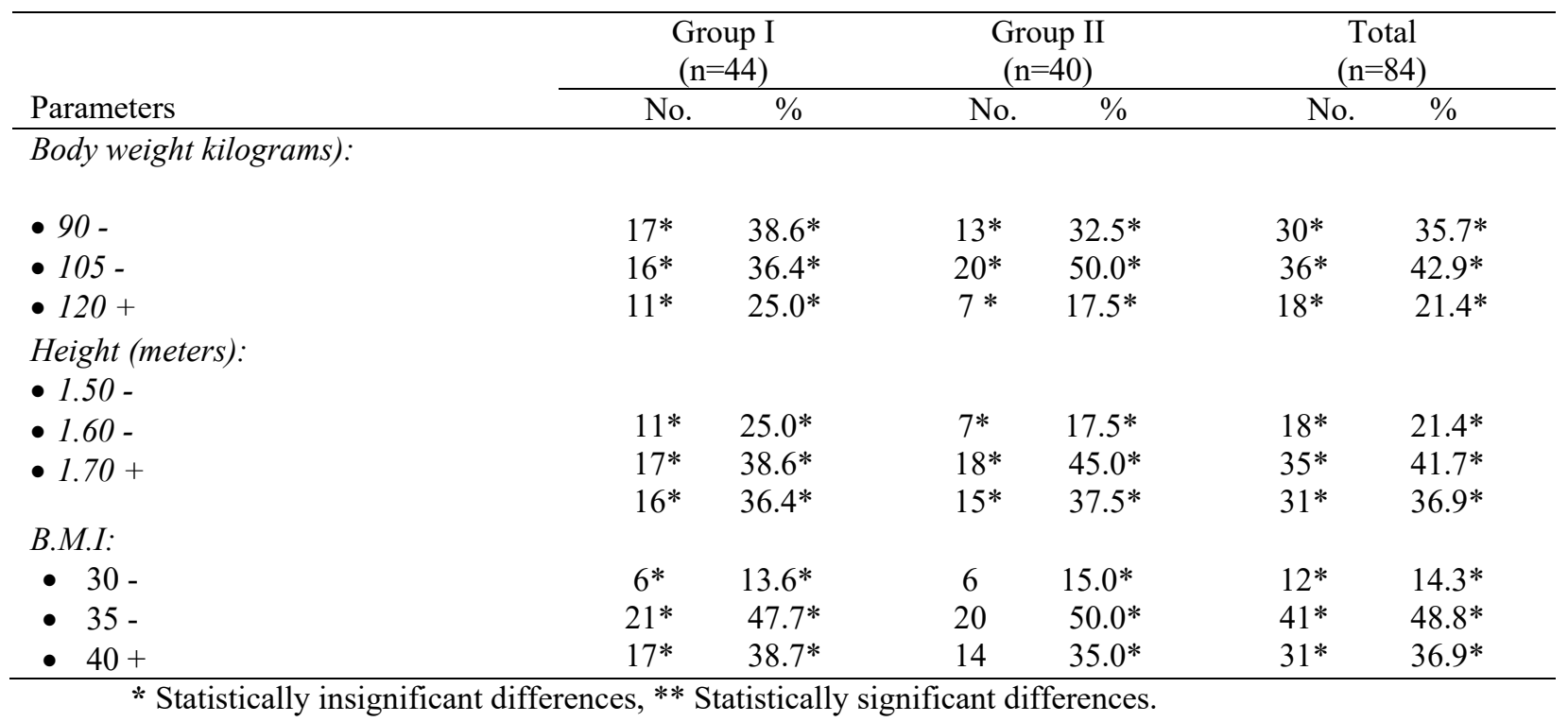

Table (4): Distribution of the studied groups according to their blood pressure and blood sugar at the beginning of the study.

\begin{tabular}{|c|c|c|c|c|c|c|}
\hline \multirow[b]{2}{*}{ Parameters } & \multicolumn{2}{|c|}{$\begin{array}{l}\text { Group I } \\
(\mathrm{n}=44)\end{array}$} & \multicolumn{2}{|c|}{$\begin{array}{c}\text { Group II } \\
(\mathrm{n}=40)\end{array}$} & \multicolumn{2}{|c|}{$\begin{array}{c}\text { Total } \\
(\mathrm{n}=84)\end{array}$} \\
\hline & No. & $\%$ & No. & $\%$ & No. & $\%$ \\
\hline Hypertensive state ${ }^{l}$ : & & & & & & \\
\hline & $28 *$ & $63.6^{*}$ & $31^{*}$ & $77.5^{*}$ & $59 *$ & $70.2^{*}$ \\
\hline & $4^{*}$ & $9.09 *$ & $0^{*}$ & $00.0^{*}$ & $4^{*}$ & $4.76^{*}$ \\
\hline$(\geq 160 / 90 \mathrm{mmhg})$ & $12 *$ & $27.3^{*}$ & 9* & $22.5^{*}$ & $21^{*}$ & $25.0^{*}$ \\
\hline Diabetic state $^{2}:$ & & & & & & \\
\hline & $30^{*}$ & $68.2^{*}$ & $28 *$ & $70.0^{*}$ & $58^{*}$ & $69.0^{*}$ \\
\hline tolerance $(\geq 140 \mathrm{mg} / \mathrm{dl})$ & $10^{*}$ & $22.7 *$ & $7 *$ & $17.5^{*}$ & $17^{*}$ & $20.2^{*}$ \\
\hline $\begin{array}{l}\text { - Diabetic } \\
(\geq 210 \mathrm{mg} / \mathrm{dl})\end{array}$ & $4^{*}$ & $9.1^{*}$ & $5^{*}$ & $12.5^{*}$ & $9 *$ & $10.7^{*}$ \\
\hline
\end{tabular}
${ }^{1}$ Suzanne (2000). \& \& ${ }^{2}$ Robert (2000).* Statistically insignificant differences.

Table (5): Comparison between the studied groups regarding their blood pressure at the beginning of the study.

\begin{tabular}{lcc}
\hline $\begin{array}{l}\text { St.gps } \\
\text { Parameter }\end{array}$ & $\begin{array}{c}\text { Group I } \\
(\mathrm{n}=44)\end{array}$ & $\begin{array}{c}\text { Group II } \\
(\mathrm{n}=40)\end{array}$ \\
\hline$\underline{\text { S.B.P }}$ & $133.9 \pm 23.52^{*}$ & 129.47 \\
$(\mathrm{mmHg})$ & & $\pm 22.51^{*}$ \\
$\underline{\mathrm{D.B.P}}$ & $82.91 \pm 8.23^{*}$ & $81.23 \pm 7.63^{*}$ \\
\hline * $\mathrm{mmH})$ & & \\
\hline Statistically insignificant differences
\end{tabular}

Table (6): Comparison between the studied groups regarding their weight, Height and Body mass index at the beginning of the study.

\begin{tabular}{lcc}
\hline $\begin{array}{l}\text { St.gps } \\
\text { Parameter }\end{array}$ & $\begin{array}{c}\text { Group I } \\
(\mathrm{n}=44)\end{array}$ & Group II $(\mathrm{n}=40)$ \\
\hline$\underline{\text { Weight }}$ & $109.64 \pm 11.64^{*}$ & $110.23 \pm 10.26^{*}$ \\
$\underline{\underline{\text { (kilogram) }}}$ & & \\
$\underline{\text { Height (meter) }}$ & $1.67 \pm 0.10^{*}$ & $1.68 \pm 0.10^{*}$ \\
B.M.I: & $39.60 \pm 4.06^{*}$ & $39.10 \pm 3.84^{*}$ \\
\hline Statistically insignificant differences
\end{tabular}


Table (7): Comparison between the studied groups regarding some laboratory biochemical investigations at the beginning of the study.

\begin{tabular}{|c|c|c|}
\hline Parameter & Group I $(n=44)$ & Group II $(n=40)$ \\
\hline Fasting blood glucose $(\mathrm{mg} / \mathrm{dl})$ & $124.68 \pm 50.94^{*}$ & $121.98 \pm 50.15^{*}$ \\
\hline Serum uric acid (mg/dl) & $7.69 \pm 2.57 *$ & $7.04 \pm 3.172 *$ \\
\hline Serum creatinine $(\mathrm{mg} / \mathrm{dl})$ & $0.95 \pm 0.297 *$ & $0.83 \pm 0.205^{*}$ \\
\hline Blood Hb. (g/dl) & $13.77 \pm 0.481^{*}$ & $13.60 \pm 0.667^{*}$ \\
\hline T. S. cholesterol (mg/dl) & $214.57 \pm 62.65^{*}$ & $199.48 \pm 44.69 *$ \\
\hline HDLc. $^{1}(\mathrm{mg} / \mathrm{dl})$ & $48.52 \pm 9.32 *$ & $46.88 \pm 7.99^{*}$ \\
\hline $\mathrm{LDLc}^{2}(\mathrm{mg} / \mathrm{dl})$ & $130.91 \pm 56.93 *$ & $118.68 \pm 43.73^{*}$ \\
\hline S. triglycerides $(\mathrm{mg} / \mathrm{dl})$ & $175.34 \pm 67.51^{*}$ & $175.08 \pm 48.14^{*}$ \\
\hline SGOT $(\mathrm{AST})^{3}(\mathrm{IU} / \mathrm{L})$ & $28.09 \pm 12.29 *$ & $28.40 \pm 6.86^{*}$ \\
\hline SGPT $(A L T)^{4}(\mathrm{IU} / \mathrm{L})$ & $27.20 \pm 10.14 *$ & $27.90 \pm 6.87 *$ \\
\hline Serum albumin $(\mathrm{g} / \mathrm{dl})$ & $3.97 \pm 0.264 *$ & $4.09 \pm 0.299 *$ \\
\hline
\end{tabular}

${ }^{1}$ HDLc. (High density lipoprotein cholesterol). ${ }^{2}$ LDLc. (Low density lipoprotein cholesterol). ${ }^{3}$ SGOT (Serum Glutamic Oxaloacetic Transaminase) or AST (Aspartata Amino Transferase).4SGPT (Serum Glutamic Pyruvate Transaminase) or ALT (Alanin Transaminase). * Statistically insignificant differences.

Table (8): Effect of weight reduction program on body weight $\&$ body mass index (BMI) among the first group.

\begin{tabular}{|c|c|c|}
\hline $\begin{array}{c}\text { St.gp I } \\
\text { Parameter }\end{array}$ & $\begin{array}{c}\text { Before W.R.P. } \\
\text { (at the beginning } \\
\text { of the study) }\end{array}$ & $\begin{array}{l}\text { After- } \\
\text { W.R.P. } \\
\text { (at the end of } \\
\text { the study) }\end{array}$ \\
\hline $\begin{array}{l}\text { Weight } \\
\text { (kilogram): }\end{array}$ & $109.64 \pm 11.64 * *$ & $91.27 \pm 10.46^{* *}$ \\
\hline BMI: & $39.60 \pm 4.094 * *$ & $32.95 \pm 3.55 * *$ \\
\hline \multicolumn{3}{|c|}{$\begin{array}{l}\text { W.R.P. }=\text { weight reduction program. } * * \text { Statistically } \\
\text { significant differences. }\end{array}$} \\
\hline \multicolumn{3}{|c|}{$\begin{array}{l}\text { Table (9): Effect of weight reduction program on } \\
\text { blood pressure among the first group. }\end{array}$} \\
\hline $\begin{array}{c}\text { St.gp I } \\
\text { Parameter }\end{array}$ & $\begin{array}{l}\text { Before W.R.P. } \\
\text { (at the beginning } \\
\text { of the study) }\end{array}$ & $\begin{array}{l}\text { After W.R.P. } \\
\text { (at the end of } \\
\text { the study) }\end{array}$ \\
\hline \multirow[t]{2}{*}{$\underline{\text { S.B.P }(\mathrm{mmHg})}$} & 133.98 & 123.93 \\
\hline & $\pm 23.52 * *$ & $\pm 10.81 * *$ \\
\hline D.B.P $(\mathrm{mmHg})$ & $82.91 \pm 8.23^{* *}$ & $79.77 \pm 5.28 * *$ \\
\hline
\end{tabular}

** Statistically significant differences

body mass index decreases. Table (9) clearly illustrates the good effect of WRP on both systolic as well as diastolic blood pressure among the first group enrolled in this study.
Their mean values are significantly decreased $(P>0.01)$. Table (10) also, shows significant decrease in fasting blood glucose, serum uric acid and serum creatinine within the group I after WRP $(P>0.01)$. It is also evident from that table a significant improvement in lipid profile. The mean value of total serum cholesterol decreases; LDLc decreases; S. triglycerides decreases while the mean value of HDLc increases. Again, a significant improvement of liver function tests was observed. The mean values of SGOT decrease from and SGPT decreases, while the mean value of serum albumin increases. The differences regarding SGOT \& S. albumin are significant $(P>0.01)$. Table (11) reveal that, by the end of following WRP, only $4.5 \%$ of the first group lost $5-10 \%$ of their original weight. $15.9 \%$ of this group decreases by 10 $15 \%$ their weight, while more than half $(59.1 \%)$ of this group decreases by $15-20 \%$ their weight. Finally, $20.5 \%$ of these obese persons lost $20 \%$ or more of their original weight. Table (12) shows that body weight \& BMI among the second group at the end of the study are nearly similar to their values at its 
Table (10): Effect of weight reduction program (WRP) on some laboratory investigations among the first group.

\begin{tabular}{lcc}
\hline $\begin{array}{l}\text { St.gp I } \\
\text { Parameter }\end{array}$ & Before W.R.P. & After W.R.P. \\
\hline Fasting blood glucose $(\mathrm{mg} / \mathrm{dl})^{* *}$ & $124.68 \pm 50.94^{* *}$ & $112.80 \pm 35.52^{* *}$ \\
Serum uric acid $(\mathrm{mg} / \mathrm{dl})^{* *}$ & $7.69 \pm 2.57^{* *}$ & $5.80 \pm 1.255^{* *}$ \\
Serum creatinine $(\mathrm{mg} / \mathrm{dl})^{* *}$ & $0.95 \pm 0.297^{* *}$ & $0.83 \pm 0.162^{* *}$ \\
Blood Hb $(\mathrm{g} / \mathrm{dl})^{*}$ & $13.77 \pm 0.481^{*}$ & $13.71 \pm 0.366^{*}$ \\
Total serum cholesterol $(\mathrm{mg} / \mathrm{dl})^{* *}$ & $214.57 \pm 62.65^{* *}$ & $180.61 \pm 33.12^{* *}$ \\
HDLc. $(\mathrm{mg} / \mathrm{dl})^{* *}$ & $48.52 \pm 9.32^{* *}$ & $61.05 \pm 5.759^{* *}$ \\
LDLc. $(\mathrm{mg} / \mathrm{dl})^{* *}$ & $130.91 \pm 56.93^{* *}$ & $90.50 \pm 29.06^{* *}$ \\
Serum triglycerides. $(\mathrm{mg} / \mathrm{dl})^{* *}$ & $175.34 \pm 67.51^{* *}$ & $148.02 \pm 33.24^{* *}$ \\
SGOT $(\mathrm{IU} / \mathrm{L})^{* *}$ & $28.09 \pm 12.29^{* *}$ & $25.36 \pm 7.945^{* *}$ \\
SGPT $(\mathrm{IU} / \mathrm{L})^{*}$ & $27.43 \pm 10.14^{*}$ & $26.20 \pm 5.994^{*}$ \\
Serum albumin $(\mathrm{g} / \mathrm{dl})^{* *}$ & $3.97 \pm 0.264^{* *}$ & $4.19 \pm 0.315^{* *}$ \\
\hline
\end{tabular}

* Statistically insignificant differences** statistically significant differences.

Table (11): Distribution of the first studied group according to the percentage of their weight loss after the weight reduction program.

\begin{tabular}{lcc}
\hline Group I & & \\
Weight loss & & \\
\hline $5 \%-$ & No. & $\%$ \\
$10 \%-$ & 2 & 4.5 \\
$15 \%-$ & 7 & 15.9 \\
$20 \%+$ & 26 & 59.1 \\
Total & 9 & 20.5 \\
\hline
\end{tabular}

${ }^{I}$ Weight Loss (W.L.) calculated as the percentage of weight at the end of the study from the original weight at the beginning of the study.

Table (12): Mean \pm S.D. of weight, Body mass index (B.M.I.) among the second group at the beginning $\&$ at the end of the study.

\begin{tabular}{llc}
\hline $\begin{array}{l}\text { St.gp II } \\
\text { Parameter }\end{array}$ & At the beginning & At the end \\
\hline Weight $(\mathrm{kg})$ & $110.23 \pm 10.26^{*}$ & $110.75 \pm 9.65^{*}$ \\
B.M.I:* & $39.14 \pm 3.84^{*}$ & $39.32 \pm 3.83^{*}$ \\
\hline
\end{tabular}

Table (13): Mean \pm S.D. of S.B.P \&D.B.P among the second group at the beginning \& at the end of the study.

\begin{tabular}{lcc}
\hline $\begin{array}{l}\text { St.gp II } \\
\text { Parameter }\end{array}$ & $\begin{array}{c}\text { At the } \\
\text { beginning }\end{array}$ & At the end \\
\hline S.B.P $(\mathrm{mmHg})$ & $129.48 \pm 22.51^{*}$ & $130.75 \pm 23.58^{*}$ \\
D.B.P $(\mathrm{mmHg})$ & $81.23 \pm 7.63^{*}$ & $81.60 \pm 7.04^{*}$ \\
\hline
\end{tabular}

beginning with a statistically insignificant differences $(P<0.05)$. Table $(13)$ clearly shows the insignificant differences $(P<0.05)$ regarding systolic $\&$ diastolic blood pressure at the start and at the end of the study among the second group.

\section{DISCUSSION}

It is evident The present work reveals that obese persons of group II, at the beginning of the study, are cross matched to those of group I regarding their gender (sex), age, residence, education and occupation [table, 1]. This means that the distribution of these variables in both groups are nearly similar with a statistically insignificant differences between both groups $(P>0.05)$. Another presentation in table [2] reveals that both groups are nearly similar as regards their mean age with a statistically insignificant difference between both groups $(P>0.05)$. These findings confirm the good selection of both groups to be cross matched or similar at the beginning of the study. Table (2), also, clarifies that in both groups; obesity is more common in females (54.8\%), Middle aged persons (69.0\% among those aged $30-45$ years), and rural residents $(81.0 \%)$, those with higher education $(73.8 \%)$ as well as among employed subjects $(54.8 \%)$. These results coincide with that of (OECD 2014) who reported that the gap in percentage of obesity is generally larger in women and 
subjects with lower socio-economic status are more likely to be obese. As regards body weight and body mass index in the present work, the third table shows that both groups are obese persons (Body weight $\geq 90 \mathrm{~K}$.gm.
\& BMI were $\geq 30$ ) with statistically insignificant differences $(P>0.05)$ at the beginning of the study. This finding, also, is a requirement in the design of the present study.

Table (14): Mean \pm S.D. of some laboratory investigations among the second group at the beginning \& at the end of the study.

\begin{tabular}{lll}
\hline $\begin{array}{l}\text { St.gp II } \\
\text { Parameter }\end{array}$ & Before W.R.P. & After W.R.P. \\
\hline Fasting blood glucose $(\mathrm{mg} / \mathrm{dl})$ & $119.58 \pm 46.77^{*}$ & $118.68 \pm 46.48^{*}$ \\
\hline Serum uric acid $(\mathrm{mg} / \mathrm{dl})$ & $7.04 \pm 3.172^{*}$ & $7.07 \pm 3.024^{*}$ \\
Serum creatinine $(\mathrm{mg} / \mathrm{dl})$ & $0.83 \pm 0.205^{*}$ & $0.87 \pm 0.119^{*}$ \\
Blood Hb $(\mathrm{g} / \mathrm{dl})$ & $13.60 \pm 0.667^{*}$ & $13.44 \pm 0.545^{*}$ \\
Total serum cholesterol $(\mathrm{mg} / \mathrm{dl})$ & $199.48 \pm 44.69^{*}$ & $199.33 \pm 44.02^{*}$ \\
HDLc. $(\mathrm{mg} / \mathrm{dl})$ & $46.88 \pm 7.99^{*}$ & $47.40 \pm 7.14^{*}$ \\
LDLc. $(\mathrm{mg} / \mathrm{dl})$ & $118.78 \pm 43.91^{*}$ & $116.25 \pm 40.65^{*}$ \\
Serum triglycerides. $(\mathrm{mg} / \mathrm{dl})$ & $178.68 \pm 52.00^{*}$ & $179.18 \pm 49.53^{*}$ \\
SGOT $(\mathrm{IU} / \mathrm{L})$ & $29.05 \pm 10.72^{*}$ & $29.80 \pm 9.379^{*}$ \\
SGPT (IU/L) & $27.90 \pm 6.88^{*}$ & $28.53 \pm 6.71^{*}$ \\
Serum albumin $(\mathrm{g} / \mathrm{dl})$ & $4.09 \pm 0.299^{*}$ & $4.010 \pm 0.32^{*}$ \\
\hline
\end{tabular}

* Statistically insignificant differences

By the end of the study, there is a significant reduction in body weight \& BMI of subjects in the first group after WRP $(P>0.01)$ [table, 8]. This finding, confirmed by the result of table (12) which shows that body weight \& BMI at the end of the study are nearly similar to their values at the beginning of the study among the group II with a statistically insignificant differences $(P>0.05)$. Also, by the end of following WRP, obese persons of the first group show loss of their original weight by different grades. Only $4.5 \%$ of this group lost $5-10 \%$ of their original weight, $15.9 \%$ of decreases by $10-15 \%$ of their weight, while more than half $(59.1 \%)$ of this group lost 15-20\% of their weight, and 20.5\% of these obese persons lost $20 \%$ or more of their original weight [table,11]. These results prove the good effect of following WRP among obese persons. These findings coincide with that of (Lawrence et al 2011) who reported that a large percentage of participants lost $5 \%$ or more of their initial body weight, an amount of weight loss that has been associated with numerous health benefits, including improved (control) of hypertension and lower levels of risk factors for cardiovascular disease. Another similar finding was obtained by (Mike 2003) who reported that obesity is an independent risk factor for a variety of diseases, including cardiovascular disease. The achievement of weight loss of 5-10\% of initial body weight is associated with a number of clinically important benefits including improvements in blood pressure and a reduced risk of mortality. Weight loss of this order in overweight and obese patients can be achieved by a variety of interventions, including low-fat diets, intensive exercise and behavioral modification. However, although most patients are able to lose weight, they find it difficult to maintain a reduced weight over the long term by reducing food intake. 
Another study carried out by (Rebecca et al 2013) reported that the effect of a clinically significant weight loss of $5 \%$ on metabolic factors among metabolically normal and abnormal overweight and obese individuals was examined. Lifestyle-based weight loss provides beneficial metabolic effects for all overweight and obese individuals. Regarding blood pressure in our study, both groups are similar in their distribution regarding their blood pressure. Hypertensive persons ( $\geq 160 / 90 \mathrm{mmhg}$ ) were $27.3 \%$ in the group I compared to $22.5 \%$ of the group II [table, 4]. Another presentation in table [5] reveals that both groups, at the beginning of the study, are nearly similar as regards their mean systolic and diastolic blood pressure. The differences between both groups regarding WRP were observed, among the group I, on both systolic and diastolic blood pressure. The mean value of systolic blood pressure was significantly decreased. The same finding was observed regarding diastolic blood pressure [table, 9]. These results together with absence of significant change among the group II from the beginning to the end of the study, confirms the beneficial effect of WRP shown among subjects of the first group regarding blood pressure [table, 13]. Also, (David Sjostrom et al 1999) reported that Intentional weight loss in the obese induced by Bariatric Surgery causes a marked reduction in the 2year incidence of hypertension. They recommend that severe obesity can and should be treated. As regards blood glucose level in this study, both groups are similar in their distribution regarding their diabetic state. Diabetics were $9.1 \%$ \& $10.7 \%$ in both groups respectively. Both groups are cross matched with statistically insignificant differences $(P>0.05)$ [table, 4]. Also, at the beginning of this study, there is a similarity between both groups regarding their fasting blood glucose. The difference between mean values of fasting blood glucose in group I compared to group II is statistically insignificant $(\mathrm{P}>0.05)$ [table, 7]. This finding confirms the cross matching state between both groups. By the end of the study, table (10) shows significant decrease in fasting blood glucose within the first group after WRP $(P<0.01)$. This is confirmed by the results obtained from table (14) which clarifies the nearly similar mean values fasting blood glucose among the second group from the start to the end of the study with a statistically insignificant difference $(P>0.05)$. Loss of excessive weight restored the abnormal glucose tolerance curve to a normal one in all cases. Another similar finding was obtained by (Lawrence et al 2011), who reported that a large percentage of participants lost $5 \%$ or more of their initial body weight, an amount of weight loss that has been associated with numerous health benefits, including improved (control) of diabetes and hypertension and lower levels of risk factors for cardiovascular disease.(Mike 2003) reported that the incidences of type- 2 diabetes and impaired glucose tolerance are very low at ideal body weight but increases with increasing body fat and BMI. Weight loss is an important goal within the overall management of diabetes, and recent intervention trials have established that the benefits of weight loss may extend to the prevention of diabetes itself. Obesity is an independent risk factor for a variety of diseases, including cardiovascular disease and type- 2 diabetes. Most features of the metabolic syndrome may be aggravated by weight gain. Regarding serum uric acid in this work, there is a similarity between both groups at the beginning of this study. The differences between the mean value of $\mathrm{s}$. uric acid were statistically insignificant $(P>0.05)$ [table, 7]. By the end of the study, table (10) shows significant decrease in serum uric acid and serum creatinine within the first group after enrolment in WRP $(P<0.01)$. Again, Table (14) clarifies the unchanged state of serum uric acid, serum creatinine, as well as blood hemoglobin among the second group from the start of the present work to its end. 
The mean values of these laboratory investigations are nearly similar with a statistically insignificant differences $(P>0.05)$. Again, (Charlotte A. et al 2009) found that patients with no weight loss had the greatest uric acid reductions whereas those with maximum weight loss had negligible falls. (Kazuko \& Gavin 2013) reported that obese individuals have frequently higher uric acid than lean individuals. Their study evaluated the effect of weight loss on serum uric acid levels and further compared the benefits of weight loss protocol on uric acid levels between calorie restricted diet and exercise. They concluded that serum uric acid levels decreased significantly in all weight loss regimens; however, a mild calorie restricted diet was more beneficial on serum uric acid reduction than exercise. As regards serum lipids in the present research, table (7) revel that there is statistically insignificant differences between both groups regarding their lipid profile $(P>0.05)$. The mean values of these lipids are nearly similar, at the beginning of this study By the end of the study, table (10) shows marked improvement in lipid profile, where the mean value of total serum cholesterol decreases; HDLc increases; LDLc decreases $\mathrm{mg} / \mathrm{dl}$ to \& Serum triglycerides decreases from. All These differences are statistically significant $(P<0.01)$. Figure (6) illustrates the effect of WRP on serum cholesterol and serum triglycerides. Table (14) shows nearly similar values of lipid profile at the start $\&$ at the end of the study among the group II with a statistically insignificant differences $(P>0.05)$. Despite the fact that our subjects were grossly overweight, the mean serumlipid levels within the range of normality. This would confirm previous observations that the simple state of obesity, like the state of leanness, in humans appears to be associated with no abnormal concentrations or patterns of serum lipids, and this lack of connection between adiposity and serum lipids is further shown by the fact that weight changes in the obese are not accompanied by parallel changes in the concentration of serum lipids. (Dattilo and Kris-Etherton 1992), in their study aiming at summarizing the results of studies that examined the effect of weight reduction by dieting on TC, LDL-C, HDLC, VLDL-C, and TG. The results showed that weight reduction was associated with a decrease in lipids. Weight loss was associated with a small and non-significant increase in HDL-C when results from the total sample were pooled. However, when results from subjects actively losing weight were analyzed, HDL-C significantly decreased Therefore, it appears that weight reduction, when maintained, has beneficial effects on the lipid profile of overweight individuals. Current recommendations to decrease weight in overweight individuals with elevated lipids are supported by results from these metaanalyses. (Erica Callahan 2012) found, in his case series, that a nutritional intervention that may assist with short-term weight loss leads to lipid profile improvement. Clinically meaningful decreases occurred for weight loss, total cholesterol levels, and LDL cholesterol levels. Finally, as regards liver function tests in this study, table (7) clearly shows the same previous findings i.e. there is statistically insignificant differences $(P>0.05)$ between both groups regarding their liver function tests at the beginning of the study. Table (10) demonstrates the significant improvement of liver function tests among group I after undergoing WRP. These findings were confirmed by the results obtained from table (14) which shows statistically insignificant differences $(P>0.05)$ regarding liver function tests from the start to the end of the study among the second group. Again, this proves the valuable effect of WRP among obese persons. This is in accordance with (Sevastianova et al 2012) who reported that weight loss restores liver fat to normal. Another finding of (Luyckx et al 1998) who reported that patients with metabolic disorders, such as obesity or 
diabetes mellitus, frequently develop 'liver steatosis', a pathology characterized by the deposition of large fat droplets in the hepatic parenchymal cells.

\section{ACKNOWLEDGMWNT}

Special Thanks for Center of Excellence in Scientific Research (CESR), fac. of vet. Med. Benha Univ. that funded by management supporting excellence (MSE) and Benha University.

\section{REFERENCES}

Barr, W., Uric Acid. In: Walker HK, Hall WD, Hurst JW, editors. Clinical Methods: The History, Physical, and Laboratory Examinations. 3rd edition. Boston: Butterworths; 1990. Chapter 165.

Billett, H., Hemoglobin and Hematocrit. In: Walker HK, Hall WD, Hurst JW, editors. Clinical Methods: The History, Physical, and Laboratory Examinations. 3rd edition. Boston: Butterworths; 1990. Chapter 151.

Busher, J., Serum Albumin and Globulin. In: Walker HK, Hall WD, Hurst JW, editors. Clinical Methods: The History, Physical, and Laboratory Examinations. 3rd edition. Boston: Butterworths; 1990. Chapter 101.

Charlotte, A., Peter, W., Bente, B., Lars, K., Emil, F., Arya, S., Nick F., Ian, C., Richard, R., Philip, J., Christian, T. 2009 Differential changes in serum uric acid concentrations in sibutramine promoted weight loss in diabetes: results from four weeks of the lead-in period of the SCOUT trial. Nutrition \& Metabolism 6:42.

Cox, R., García-Palmieri, M,. Cholesterol Triglycerides and Associated Lipoproteins. In: Walker HK, Hall WD, Hurst JW, editors. Clinical Methods: The History, Physical, and Laboratory
Examinations. 3rd edition. Boston: Butterworths; 1990. Chapter 31.

Dattilo, A., Kris-Etherton, P. 1992. Effects of weight reduction on blood lipids and lipoproteins: a meta-analysis Am. J. Clinical Nutrition; 56:320-8.

David, S., Lauren, L., Hans, W., Lars, S. 1999. Reduction in Incidence of Diabetes, Hypertension and Lipid Disturbances after Intentional Weight Loss Induced by Bariatric Surgery, the SOS Intervention Study.

Erica, C. 2012. Changes in weight loss and lipid profiles after a dietary purification program: a prospective case series.

Finkelstein, E., Fiebelkorn, I., Wang, G. 2003. National medical spending attributable to overweight and obesity: how much, and who's paying? Suppl Web Exclusives: W3-219-W3-226.

Fitch, A., Everling, L., Fox, C., Goldberg, J., Heim, C., Johnson K., Kaufman, T., Kennedy, E., Kestenbaun, C., Lano, M., Leslie, D., Newell, T., O'Connor, P., Slusarek, B., Spaniol, A., Stovitz, S., Webb, B. 2013. Institute for Clinical Systems Improvement. Prevention and Management of Obesity for Adults, Sixth Edition, https://www.icsi.org/ Institute for Clinical Systems Improvement.

Han, T., Abdelouahid, T., Lean, M. 2011. Obesity and weight management in the elderly., Published Online, Downloaded from: http://bmb.oxfordjournals.org/

Hosten, A., BUN and Creatinine. In: Walker HK, Hall WD, Hurst JW, editors. Clinical Methods: The History, Physical, and Laboratory Examinations. 3rd edition. Boston: Butterworths; 1990. Chapter 193.

Kazuko, M., Gavin, W. 2013. Effects of Weight Loss on Serum Uric Acid Concentrations,. Circulation; 127: AP026. Baker IDI Heart' Diabetes Institute, Melbourne Vic, Australia 
Kopelman, 2000. Obesity as a medical problem. NATURE, VOL, 404, www.nature.com. Macmillan Magazines Ltd.

Lawrence, A., Jeanne C., Hsin-Chieh, Y., Nae-Yuh, W., Janelle, C., Gail, D., Edgar, M., Arlene, D., Gerald, J., Steven, G., Gary, N., Thomas, P., Jeanne, C. R., Jeffrey, R., Nowella, D., Richard, R., Thomas, L. , Frederick, B. 2011. Comparative Effectiveness of Weight-Loss Interventions in Clinical Practice. The New England Journal of Medicine 365: 21.

Luyckx, F., Desaive, C., Thiry, A., DeweÂ, W., Scheen, A., Gielen, J., LefeÁbvre, P. 1998. Liver abnormalities in severely obese subjects: Effect of drastic weight loss after gastroplasty. Belgium International Journal of Obesity, 22.

McMillin, J., Blood Glucose. In: Walker HK, Hall WD, Hurst JW, editors. Clinical Methods: The History, Physical, and Laboratory Examinations. 3rd edition. Boston: Butterworths; 1990. Chapter 141.

Meredith, C., Matilde, S., Brian, R., Neil, J., Steven, R., William, R., Christen, M. 2011. A One-Year randomized Trial of Lorcaserin for Weight Loss in Obese and Overweight Adults. The BLOSSOM Clinical Trial Group. J. Clin. Endocrinol. Metab, 96(10):30673077.

Mike, L. 2003. Is there a metabolic rationale to support a weight loss programme to prevent diabetes? The British journal of diabetes and vascular disease; 3 (suppl 1): S12-S17.

OECD, Directorate for Employment, Labour and Social Affairs, 2014. OBESITY Update Source: OECD Health Statistics www.oecd.org/health/healthdata.

Rebecca, H.L., Sean, W., Arya, M. S., Chris, I. A., Jennifer, L. K. 2013. Influence of a Clinical Lifestyle-Based Weight Loss
Program on the Metabolic Risk Profile of Metabolically Normal and Abnormal Obese Adults. Obesity, 21:1533-1539. Sevastianova, K., Santos, A., Kotronen, A., Hakkarainen, A., Makkonen, J., Silander, K., Peltonen, M., Romeo, S., Lundbom, J., Lundbom, N., Olkkonen, V., Gylling, H., Fielding, B., Rissanen, A., Yki-Ja"rvinen, H. 2012. Effect of short-term carbohydrate overfeeding and long-term weight loss on liver fat in overweight humans. The American Journal of Clinical Nutrition October, 96(4):727-734.

Thang, S., Naveed S., Mike, L., (2006): Assessment of obesity and its clinical implications. $\mathrm{ABC}$ of obesity. BMJ; 333:695-698.

WHO, 2003. Obesity and Overweight, "Global Strategy on diet, physical activity and health".

Vroon, D., Israili, Z., Aminotransferases. In: Walker HK, Hall WD, Hurst JW, editors. Clinical Methods: The History, Physical, and Laboratory Examinations. 3rd edition. Boston: Butterworths; 1990. Chapter 99 Barr, W., Uric Acid. In: Walker HK, Hall WD, Hurst JW, editors. Clinical Methods: The History, Physical, and Laboratory Examinations. 3rd edition. Boston: Butterworths; 1990. Chapter 165. 